i relacje w nim zachodzące na przestrzeni wieków autor odkrywa przed czytelnikiem. Zaś historykom oświaty dostarcza wiele przykładów świetnie ilustrujących zajęcia dydaktyczne oraz, co najważniejsze, wskazuje niezbadane jeszcze obszary wiedzy.

Jolanta Szablicka

\title{
Czesław Kupisiewcz, $Z$ dziejów teorii $i$ praktyki wychowania, Oficyna Wydawnicza „Impuls”, Warszawa 2012, ss. 322
}

Nakładem Oficyny Wydawniczej „Impuls”, specjalizującej się w literaturze naukowej, ukazał się niedawno podręcznik akademicki $Z$ dziejów teorii i praktyki wychowania. Autorem książki jest nestor polskiej pedagogiki, zwany „Nauczycielem nauczycieli”, profesor Czesław Kupisiewicz. Ten uczony z wieloletnim dorobkiem podjął się napisania pozycji, która w efekcie finalnym ma przystępny charakter wprowadzający nie tylko dla studentów pedagogiki i nauczycieli, ale także wszystkich osób mających coś wspólnego z oświatą i edukacją, a nawet jest atrakcyjna dla czytelników zainteresowanych poszerzeniem horyzontów umysłowych i wiedzy o kulturze humanistycznej Zachodu.

Problem wychowania nie jest bowiem zagadnieniem błahym ani abstrakcyjnym. Wychowanie, jak definiuje autor, to ogót czynności zwiqzanych z oddziaływaniem środowiska przyrodniczego i społecznego na człowieka, ksztattujacych jego osobowość i trwajacych przez cate życie. Wychowanie nie ogranicza się zatem do okresu dzieciństwa i młodości, jest procesem trwającym permanentnie. Prawidłowe wychowanie może wzmacniać i stymulować podstawy funkcjonowania jednostek oraz społeczeństwa, a nawet powodować, że dana cywilizacja (jak na przykład antyczna cywilizacja grecka z jej ideałem kalokagatii), wznosi się na wyżyny ducha i twórczej ekspresji kulturowej. Nieprawidłowe zaś wychowanie, wynikające ze złych wpływów środowiska, może doprowadzić na przykład do przestępczości. Jak pisze Locke, jeden z wielu autorów omawianych przez Kupisiewcza: „Z dziesięciu ludzi, których spotykamy, dziewięciu jest tym, czym jest: złymi lub dobrymi, pożytecznymi lub szkodliwymi dla społeczeństwa - dzięki wychowaniu".

Pierwsze wrażenie z obcowania czytelniczego z książką Kupisiewcza jest niezwykle przyjemne. Podręcznik jest atrakcyjny w lekturze, zawierający w sobie bardzo uporządkowany i oszczędny materiał. Każdy rozdział posiada swoje wyszczególnienia, streszczające tezy omawianych koncepcji i myślicieli (z których prawie każdy posiada swoją małą ilustrację w książce), zawsze odnajdziemy również w danej partii tekstu zgrabne podsumowanie oraz słownik najważniejszych przywoływanych teminów. Zarazem książka posiada bardzo skondensowaną dawkę syntezy z dziejów całej zachodniej myśli pedagogicznej, dotyczącej teorii i praktyki wychowania.

Wrażenia po dłuższej lekturze książki Kupisiewcza także są pozytywne. Autor przeprowadza czytelnika, niczym Charon przez Styks, przez złożone i wielowątkowe dzieje myśli pedagogicznej oraz instytucji, zajmujących się wychowywaniem. Na kartach pod- 
ręcznika pojawiają się zarówno postacie bardzo znane z filozofii i historii nauki - jak Platon, Arystoteles, św. Tomasz z Akwinu, czy Jean Rousseau, jak i te mniej znane, a mające również swój wkład w ,wychowywanie” w kulturze zachodniej. Mowa tu chociażby o królu Wessexu - Alfredzie Wielkim, który odbudowywał oświatę w zniszczonej najazdami Anglii IX w. Okazuje się również z lektury podręcznika, że bez działalności oświatowej nie byłoby możliwe szerzenie różnych idei danej epoki - na przykład Marcin Luter niewiele by zdziałał w swoich działaniach reformacyjnych, gdyby nie zorganizowana aktywność edukacyjna Filipa Melanchtona.

Kupisiewcz uświadamia czytelnikowi, jak wielowiekowy i żmudny był rozwój dwóch podstawowych instytucji wychowawczych - rodziny i szkoły. Wzajemne relacje między tymi elementami stanowią również jeden z osiowych wątków tej książki. I tak, w starożytnym Rzymie rola rodziny i wychowania moralnego była nie do przecenienia, ale towarzyszyło mu również powstanie pierwszych szkół, które autor datuje na 149. r. p.n.e. (wcześniejsza starożytna działalność Platońskiej Akademii i Arystototelejskiego Liceum miała charakter zbyt elitarny). Przypomina o początkach płatnego nauczania (grecki ruch sofistów), o rozwoju szkolnictwa w wiekach średnich (ideał nauk Artes Liberales, czy małe szkoły parafialne - zaczątek powszechnej edukacji elementarnej w nowożytności). Mało kto wie, że pierwszym twórcą systemu klasowo-lekcyjnego, tak oczywistego dziś, był Johann Sturm, uczeń wspomnianego Melanchtona.

W podręczniku przedstawiona jest interesująca panorama sporów pedagogicznych wokół teorii i praktyka wychowania. Czy należy prowadzić edukację raczej formalną i dyscyplinującą (co wciąż wydaje się dominuje w polskich szkołach), czy może edukację nastawioną na partnerską relację między uczniem a nauczycielem? Czy ważniejsze w wychowaniu są klasyczne nauki humanistyczne, czy realno-przyrodnicze? Jakie są różnice między wychowaniem a nauczaniem? Na te pytania Kupisiewcz nie udziela jednoznacznej odpowiedzi, ale pokazuje jak historycznie zmieniały się różne stanowiska pedagogiczne. Interesujący jest również rozdział dotyczący współczesnej pedagogiki, pokazujący jak pluralistyczne są rozwiązania wokół problemu wychowania. Nurt Nowego Wychowania, różne kierunki pedagogiki kultury, ale także i „twarde” propozycje wychowawcze badaczy behawioralnych, czy z kręgu naturalistycznego - wszystkie te koncepcje mają swoje miejsce w tym ponad trzystustronicowym podręczniku. Prawdziwa skarbnica myśli edukacyjnej, pokazująca również związki między filozofią a pedagogiką.

Książka Czesława Kupisiewicza nie jest niestety wolna od różnych błędów merytorycznych. Na stronie 18 podana jest nieprawidłowa data bitwy Filipa II Macedońskiego pod Cheroneą (w druku jest 474 rok, powinien być 338). Na tej samej stronie jest wzmiankowa „kultura myceńska”, podczas gdy autor ma na myśli z pewnością „kulturę mykeńską". Na stronie 26 wymienione są dwa różne dzieła Platona - Rzeczpospolita i Państwo, które są przecież tym samym dziełem. Na stronie 131 autor twierdzi, że nowożytny ruch religijny jansenizmu powstał w XVIII w., podczas gdy w rzeczywistości powstał stulecie wcześniej. Na stronie 139 autor przypisuje sentencję: „Nie ma niczego w umyśle, czego wcześniej nie byłoby w zmyśle” Johnowi Locke’owi, podczas gdy pierwszy tę tezę wypowiedział Arystoteles. W książce zdarzają się również usterki chronologiczne - na przykład Pitagoras pojawia się po Arystotelesie, podczas gdy żył od 
niego znacznie wcześniej. W rozdziale poświęconym Diderotowi autor odwołuje się do Helwecjusza, który jest omówiony dopiero parę stron później. Wątpliwości budzą niektóre definicje przyjęte przez autora, np. że „ontologia określa cel życia człowieka” [s. 28] - to bardziej czyni normatywna etyka lub antropologia filozoficzna, niż ontologia zajmująca się opisem bytu metafizycznego. Jeszcze jedną moją uwagą krytyczną wobec podręcznika Kupisiewicza jest wysoki europocentryzm tej pozycji. Skoro bowiem mowa o powszechnej syntezie poglądów na wychowanie w dziejach - dlaczego nie znalazły się tu krótkie chociaż rozdziały na temat edukacji w mandaryńskiej kulturze chińskiej, czy kastowym systemie braminów w Indiach?

Wszystkie te powyższe zarzuty nie mają jednak charakteru pierwszorzędnego ani nie deprecjonują wysokich walorów dydaktycznych i akademickich recenzowanej publikacji. Można ją z czystym sumieniem polecić wszystkim osobom zainteresowanym nie tylko pedagogika, ale przede wszystkim bogatą historią wychowania w kulturze zachodniej. Zaryzykuję nawet twierdzenie, że jest to pozycja obowiązkowa na półce każdego polskiego inteligenta, pretendującego do erudycji humanistycznej.

Juliusz Iwanicki

\section{Dorota Żołądź-Strzelczyk, Katarzyna Kabacińska-łuczak, Codzienność dziecięca opisana slowem i obrazem. Życie dziecka na ziemiach polskich od XVI do XVIII wieku, Wydawnictwo DiG, Warszawa 2012, ss. 190}

W ostatnich dekadach problematyka dziecka i dzieciństwa stała się przedmiotem analiz i badań naukowców z wielu dziedzin, czego wynikiem są liczne opracowania o charakterze historycznym, pedagogicznym, historyczno-pedagogicznym, socjologicznym, etnograficznym, antropologicznym, filozoficznym. Ta wielość spojrzeń na wskazane problemy pozwala na odnalezienie różnorodnych sposobów rozumienia dziecka i dzieciństwa, wskazanie różnych modeli dzieciństwa zarówno w minionej przeszłości, jak i współcześnie.

Jedną z najnowszych prac poświęconych dziecku w ujęciu historyczno-pedagogicznym jest praca autorstwa Doroty Żołądź-Strzelczyk i Katarzyny Kabacińskiej, które przedmiotem swych badań uczyniły codzienność dziecięcą na ziemiach polskich od XVI do XVIII w. Autorki ukazują czytelnikowi świat dzieciństwa, charakteryzując warunki, miejsca i przestrzeń funkcjonowania dzieci, elementy kultury materialnej związanej z dziećmi w różnych przedziałach wiekowych i różnych stanach, tworząc tym samym niezwykle interesujący, barwny i stosunkowo wszechstronny obraz życia najmłodszych członków społeczeństwa na ziemiach polskich okresu przedrozbiorowego. Warto w tym miejscu podkreślić, że publikacja stanowi swoistą kontynuację prowadzonych wcześniej przez Dorotę Żołądź-Strzelczyk badań nad dzieckiem i dzieciństwem doby staropolskiej, których wyniki zamieszone zostały w pracy Dziecko w dawnej Polsce (Poznań 2002, 2006). W charakteryzowanej pracy cześć prezentowanych wcześniej treści została zna- 